\title{
PERBANDINGAN KADAR ASAM URAT PADA SUBYEK OBES DAN NON-OBES DI FAKULTAS KEDOKTERAN UNIVERSITAS SAM RATULANGI MANADO
}

\author{
${ }^{1}$ Elim Rau \\ ${ }^{2}$ Jeffrey Ongkowijaya \\ ${ }^{2}$ Ventje Kawengian
}

\author{
${ }^{1}$ Kandidat Skripsi Fakultas Kedokteran Universitas Sam Ratulangi Manado \\ ${ }^{2}$ Bagian Ilmu Penyakit Dalam BLU RSUP Prof. Dr. R. D. Kandou Manado \\ Email: rauelim@gmail.com
}

\begin{abstract}
Uric acid is the end product of purine metabolism. Circulating uric acid in the human body is produced by the body (endogenous uric acid) as well as derived from food (exogenous uric acid). Normal serum uric acid level is $<7.0 \mathrm{mg} / \mathrm{dL}$ in men and $<6.0$ in women. Obesity can be defined as excess body fat. One of the markers used for body fat content is body mass index (BMI). This study aimed to compare the levels of uric acid in obese and non-obese subjects. This was an analytical study with a cross sectional design. The population is students of Faculty of Medicine University of Sam Ratulangi Manado. Samples were male students of batch 2013. There were 42 male students, consisted of 21 obese and 21 non-obese students. The results showed that the average of uric acid levels in obese group was $8.05 \mathrm{mg} / \mathrm{dL}$ and in non-obese group $6.63 \mathrm{mg} / \mathrm{dL}$. In the obese group, $67 \%$ had an increase in uric acid level meanwhile in the non-obese group only $38 \%$. The statistical test showed a sig 0,009. Conclusion: In this study, the average of uric acid level in obese group was significantly higher than in the non-obese group. However, there were students with either normal or high uric acid levels in both groups.
\end{abstract}

Keywords: uric acid, obese

\begin{abstract}
Abstrak: Asam urat merupakan produk akhir metabolisme purin. Asam urat yang beredar di dalam tubuh manusia di produksi sendiri oleh tubuh (asam urat endogen) dan berasal dari makanan (asam urat eksogen). Normalnya kadar asam urat serum $<7,0 \mathrm{mg} / \mathrm{dL}$ pada pria dan $<6,0 \mathrm{mg} / \mathrm{dL}$ pada wanita. Obesitas dapat di definisikan sebagai kelebihan lemak tubuh. Penanda kandungan lemak tubuh yang digunakan ialah indeks masa tubuh (IMT). Penelitian ini bertujuan untuk mengetahui perbandingan kadar asam urat pada subyek obes dan non obes. Penelitian ini bersifat analitik dengan pendekatan potong lintang. Populasi penelitian ialah mahasiswa Fakultas Kedokteran Universitas Sam Ratulangi Manado. Sampel idalah mahasiswa pria angkatan 2013 dan didapatkan 42 orang yang terbagi atas 21 obes dan 21 non obes. Hasil penelitian memperlihatkan rerata kadar asam urat pada obes 8,05 mg/dL dan pada non-obes $6,63 \mathrm{mg} / \mathrm{dL}$. Peningkatan kadar asam urat ditemukan 67\% pada kelompok obes dan $38 \%$ pada kelompok non-obes. Uji statistik menunjukkan nilai sig 0,009. Simpulan: Pada penelitian ini rerata kadar asam urat pada kelompok obes lebih tinggi secara bermakna daripada kelompok non-obes. Walaupun demikian, pada kedua kelompok ditemukan mahasiswa dengan kadar asam urat normal maupun meningkat.
\end{abstract}

Kata kunci: asam urat, obesitas

Asam urat merupakan produk akhir metabolisme purin. Asam urat yang beredar di dalam tubuh manusia diproduksi sendiri oleh tubuh (asam urat endogen) dan juga 
diperoleh dari makanan (asam urat eksogen). ${ }^{1}$ Asam urat terutama diekskresikan melalui ginjal, dimana akan terfiltrasi keseluruhan di glomerulus, direabsobsi di tubulus proksimal, lalu disekresikan dan akhirnya direabsorbsi kembali sebagian; sekitar $10 \%$ akan di ekskresikan. $^{2}$

Kadar asam urat serum mengikuti distribusi normal pada populasi umum namun kadar asam urat pada pria lebih tinggi dari pada wanita. Normalnya kadar asam urat serum adalah kurang dari 7,0 $\mathrm{ml} / \mathrm{dl}$ pada pria dan kurang dari 6,0 mg/dl pada wanita. Meskipun faktor genetik memainkan peranan penting dalam regulasi kadar asam urat serum, namun peningkatan asupan purin atau faktor lain seperti fruktosa juga dapat mempengaruhi metabolisme asam urat. $^{3,4}$ Selain itu, banyak faktor yang dapat mempengaruhi konsentrasi asam urat, misalnya: diet, obesitas, dan Sindrom Metabolik.

Prevalensi hiperurisemia asimptomatik di Amerika Serikat adalah 5\%, sedangkan di Inggris sekitar 6,6\% dan di Scotlandia sebesar 8\%. Di New Zealand, hiperurisemia lebih banyak di jumpai pada laki-laki dari suku Maori (27,1\%) di bandingkan dengan laki-laki Eropa (9,4\%). Penelitian di Atayal, Taiwan pada 342 populasi di atas 18 tahun menunjukkan bahwa kejadian hiperurisemia sekitar $41,4 \%$. Satu survei epidemiologik yang di lakukan di Bandungan, Jawa Tengah atas kerjasama WHO-COPCORD terhadap 4.683 sampel berusia antara 15 - 45 tahun didapatkan bahwa prevalensi hiperurisemia sebesar 24,3\% pada laki-laki dan 11,7\% pada wanita. Secara keseluruhan prevalensi kedua jenis kelamin 17,6\%. ${ }^{6}$ Di Minahasa, prevalensi hiperurisemia pada laki-laki dewasa muda 34,40\% seddangkan hiperurisemia asimptomatik 33,68\%. ${ }^{7}$

Hiperurisemia pada obesitas terjadi melalui resistensi hormon insulin. Pada tubuh yang akan mengalami obesitas akan terjadi peningkatan pelepasan jumlah asam lemak bebas ke dalam sirkulasi. Masuknya asam lemak bebas yang berlebihan ini ke dalam otot mengakibatkan terjadinya resistensi insulin. Resistensi insulin, hipoksia, dan kematian sel dapat menginduksi perubahan xanthine dengan bantuan air dan oksigen akan berubah menjadi asam urat yang menghasilkan peroksida. Insulin juga berperan dalam meningkatkan reabsorbsi asam urat di tubuli proksimal ginjal. Sehingga pada keadaan hiperinsulinemia pada pra diabetes terjadi peningkatan reabsorbsi yang akan menyebabkan hiperurisemia. ${ }^{8,9}$

Obesitas dapat didefinisikan sebagai kelebihan lemak tubuh. Penanda kandungan lemak tubuh yang digunakan adalah indeks masa tubuh (IMT), yang dapat dihitung sebagai Berat badan $(\mathrm{kg}) /$ Tinggi badan $\left(\mathrm{m}^{2}\right)$. Secara klinis, IMT yang bernilai 25 dan 29,9 kg/m ${ }^{2}$ disebut berat badan lebih, dan nilai IMT lebih dari $30 \mathrm{~kg} / \mathrm{m}^{2}$ disebut obes. ${ }^{10}$

Prevalensi obesitas pada anak dan dewasa di Amerika Serikat dan di banyak negara maju lainnya sangat meningkat, yang bertambah lebih dari 30\% selama dekade terakhir. Kira-kira 64\% orang dewasa di Amerika Serikat mengalami berat badan lebih, dan hampir 33\% mengalami obesitas. Berdasarkan RISKESDAS nasional pada tahun 2010, prevalensi obesitas di Indonesia adalah 7,8\% untuk laki-laki dan 15,5\% untuk perempuan. Sulawesi utara dengan 14,3 laki-laki dan 29,5 perempuan obes memiliki prevalensi obesitas tertinggi (37,1\%) dibandingkan dengan provinsi lain di Indonesia. ${ }^{10,11}$

Terdapat kesamaan antara orang yang mengalami hiperurisemia dan yang obesitas yaitu pola makan yang tidak terkontrol. Dari penelitian di sebutkan bahwa faktorfaktor yang berhubungan dengan kejadian hiperurisemia adalah jenis kelamin, IMT, konsumsi alkohol, interaksi obat, asupan karbohidrat dan asupan purin. Beberapa penelitian yang menyebutkan bahwa tidak ada hubungan antara hiperurisemia dengan obesitas. $^{12-13}$

\section{METODE PENELITIAN}

Penelitian ini bersifat analitik dengan pendekatan potong lintang. Tempat 
penelitian di Fakultas Kedokteran Universitas Sam Ratulangi Manado dan dilaksanakan pada bulan OktoberNovember. Populasi penelitian ini ialah mahasiswa Kedokteran Universitas Sam Ratulangi dengan sampel pria angkatan 2013. Variabel penelitian ialah kadar asam urat dan Indeks Masa Tubuh (IMT).

\section{HASIL PENELITIAN}

Dari hasil karakteristik penelitian di dapatkan sampel mahasiswa obes dengan IMT $>30$ sebanyak 21 orang dengan rerata asam urat 8,05 mg/dL (Tabel 1). Pada sampel mahasiswa non obes dengan IMT
$<25$ didapatkan sebanyak 21 orang dengan rerata kadar asam urat 6,63 $\mathrm{mg} / \mathrm{dL}$ (Tabel 2).

\section{Distribusi kadar asam urat}

Dari hasil penelitian yang mengalami peningkatan kadar asam urat pada subyek obes sebanyak 14 orang (67\%) dan 7 orang tidak mengalami kadar asam urat (33\%) (Gambar 1). Pada subyek non obes sebanyak 8 orang mengalami peningkatan kadar asam urat (38\%) dan 13 orang (62\%) tidak mengalami penigkatan kadar asam urat (Gambar 2).

Tabel 1. Karakteristik hasil penelitian pada mahasiswa obes

\begin{tabular}{|c|c|c|c|c|c|c|}
\hline & $\mathrm{N}$ & Min & Max & Rata-rata & Median & Modus \\
\hline & 21 orang & & & & & \\
\hline Umur & & 18 tahun & 21 tahun & 19 Tahun & 19 tahun & 18 tahun \\
\hline $\begin{array}{l}\text { Berat } \\
\text { badan }\end{array}$ & & 77 Kg & $108 \mathrm{Kg}$ & $92 \mathrm{Kg}$ & $90 \mathrm{Kg}$ & $90 \mathrm{Kg}$ \\
\hline $\begin{array}{l}\text { Tinggi } \\
\text { badan }\end{array}$ & & $158,5 \mathrm{~cm}$ & $182,5 \mathrm{~cm}$ & $168,1 \mathrm{~cm}$ & $169,5 \mathrm{~cm}$ & $161 \mathrm{~cm}$ \\
\hline IMT & & $\begin{array}{l}30,12 \\
\mathrm{~kg} / \mathrm{m}^{2}\end{array}$ & $\begin{array}{l}35,90 \\
\mathrm{~kg} / \mathrm{m}^{2}\end{array}$ & $32,66 \mathrm{~kg} / \mathrm{m}^{2}$ & $32,57 \mathrm{~kg} / \mathrm{m}^{2}$ & \\
\hline $\begin{array}{c}\text { Kadar } \\
\text { asam urat }\end{array}$ & & $\begin{array}{c}\text { 5,0 } \\
\mathrm{mg} / \mathrm{dL}\end{array}$ & $\begin{array}{c}12,6 \\
\mathrm{mg} / \mathrm{dL}\end{array}$ & 8,05mg/dL & 7,8mg/dL & 9,4mg/dL \\
\hline
\end{tabular}

Tabel 2. Karakteristik hasil penelitian pada mahasiswa non obes

\begin{tabular}{|c|c|c|c|c|c|c|}
\hline & $\mathrm{N}$ & Min & Max & Rata-rata & Median & Modus \\
\hline & 21 orang & & & & & \\
\hline Umur & & 18 tahun & 20 tahun & 19 Tahun & 19 tahun & 19 tahun \\
\hline $\begin{array}{l}\text { Berat } \\
\text { badan }\end{array}$ & & $55 \mathrm{Kg}$ & $80 \mathrm{Kg}$ & $64 \mathrm{Kg}$ & $65 \mathrm{Kg}$ & $56 \mathrm{Kg}$ \\
\hline $\begin{array}{l}\text { Tinggi } \\
\text { badan }\end{array}$ & & $162 \mathrm{~cm}$ & $181,9 \mathrm{~cm}$ & $169,8 \mathrm{~cm}$ & $168,5 \mathrm{~cm}$ & $167 \mathrm{~cm}$ \\
\hline IMT & & $\begin{array}{l}19,78 \\
\mathrm{~kg} / \mathrm{m}^{2}\end{array}$ & $\begin{array}{l}24,82 \\
\mathrm{~kg} / \mathrm{m}^{2}\end{array}$ & $22,34 \mathrm{~kg} / \mathrm{m}^{2}$ & $22,45 \mathrm{~kg} / \mathrm{m}^{2}$ & \\
\hline Kadar & & 4,1 & 9,6 & 6,63mg/dL & 6,6mg/dL & $6,2 \mathrm{mg} / \mathrm{dL}$ \\
\hline asam urat & & mg/dL & mg/dL & & & \\
\hline
\end{tabular}

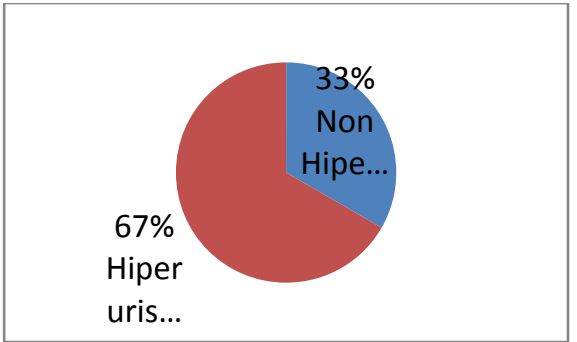

Gambar 1. Persentase kadar asam urat pada mahasiswa obes

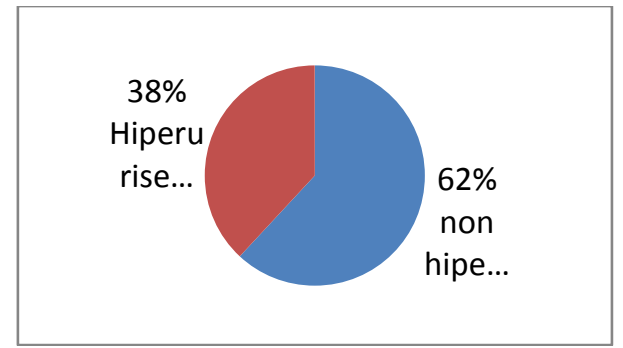

Gambar 2. Persentase kadar asam urat mahasiswa non obes 
Distribusi kdar asam urat menurut umur

Berdasarkan hasil penelitian pada mahasiswa obes di dapatkan bahwa umur 20 tahun paling tinggi kadar asam urat dengan jumlah sampel 5 orang (Tabel 3).
Pada mahasiswa non obes didapatkan bahwa umur 20 tahun paling tinggi kadar asam urat dengan jumlah sampel 4 orang meskipun belum di kelompokkan sebagai peningkatan kadar asam urat.

Tabel 3. Distribusi kadar asam urat mahasiswa obes menurut umur

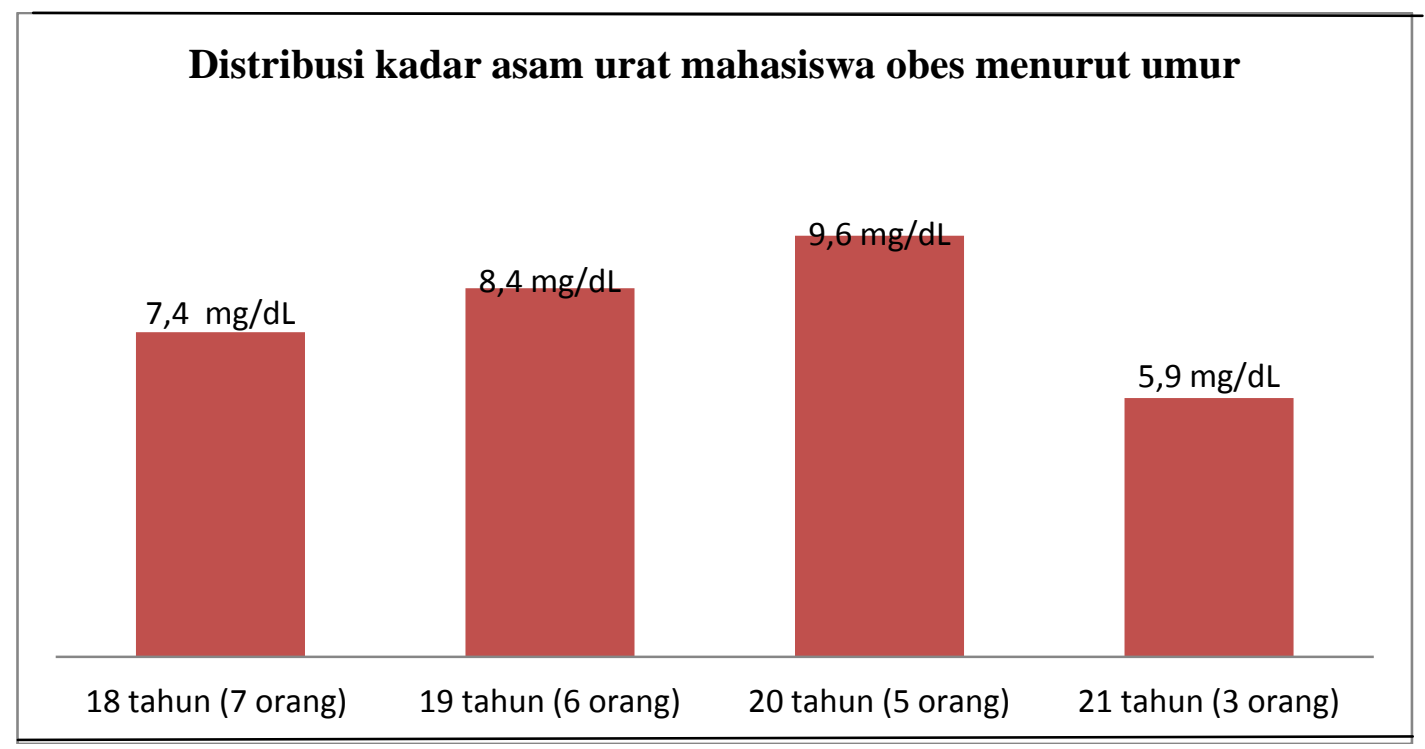

Tabel 4. Distribusi kadar asam urat mahasiswa non obes menurut umur

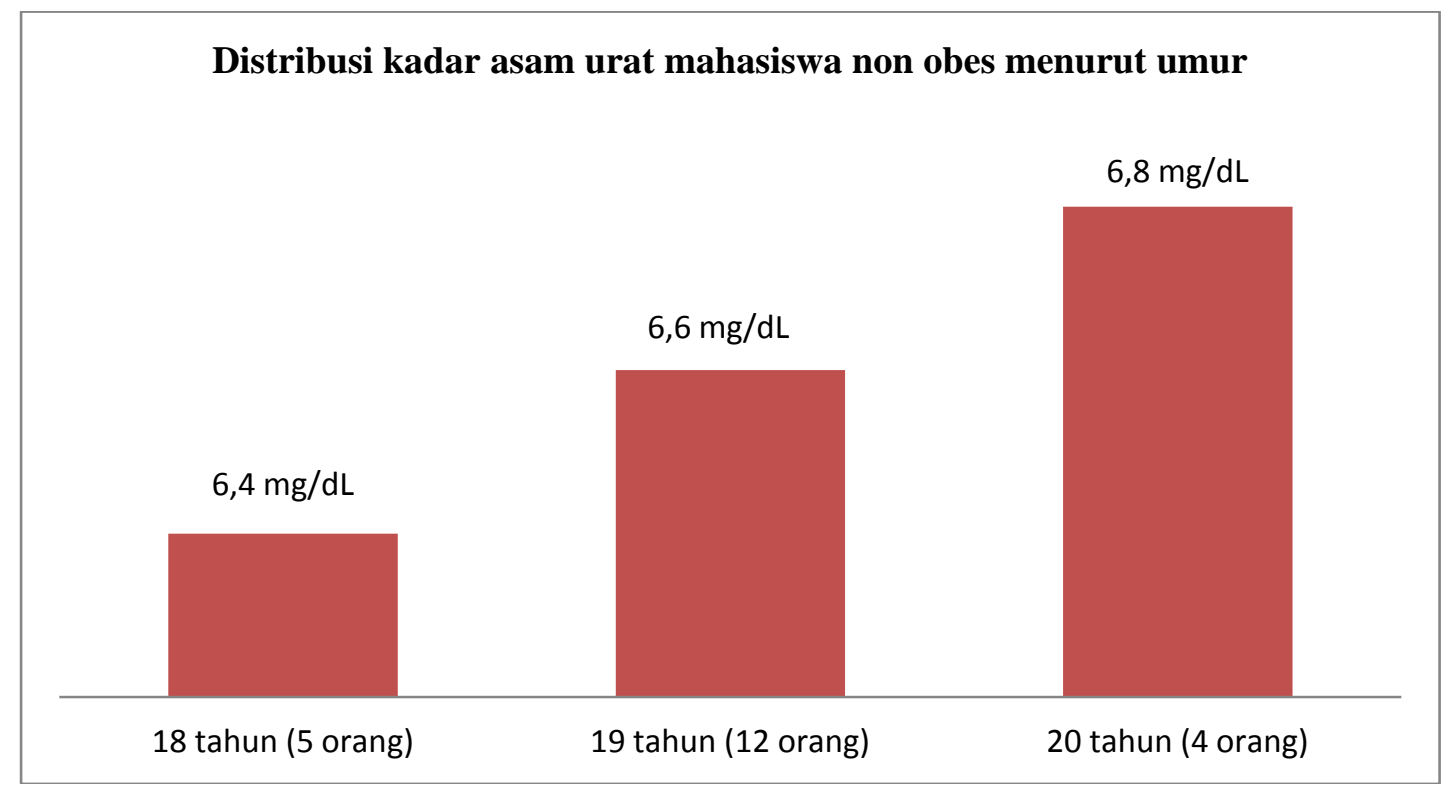

\section{Uji statistik}

Hasil uji statistik menunjukkan rerata kadar asam urat kelompok obes 8,057 dan kelompok non obes 6,624 dengan nilai signifikansi sebesar 0,009. 
Jurnal e-Clinic (eCl), Volume 3, Nomor 2, Mei-Agustus 2015

Tabel 6. Uji Statistik mann Whitney

\begin{tabular}{cccc}
\hline Variabel & Kelompok obes & Kelompok non obes & Sig \\
\hline Asam urat & 8,057 & 6,624 & 0,009 \\
\hline
\end{tabular}

\section{BAHASAN}

Jumlah subjek pria 42 orang terdiri dari 21 orang obese dan 21 orang non obese. Seluruh responden dimintakan persetujuan telebih dahulu sebelum pemeriksaan. Responden terlebih dahulu puasa selama 10 jam sebelum diambil darah untuk pengukuran asam urat. Usia dari subjek penelitian bervariasi 18-21 tahun. Berat badan responden bervariasi $55-108 \mathrm{~kg}$, tinggi badan $158,5-181,9 \mathrm{~cm}$, dan IMT $19,78-35,85 \mathrm{~kg} / \mathrm{m}^{2}$. Kadar asam urat dimulai dari 4,1 mg/dL sampai 12,6 $\mathrm{mg} / \mathrm{dL}$. Mahasiswa obes yang mengalami hiperurisemia berjumlah 14 orang (67\%) dan yang tidak mengalami hiperurisemia 7 (33\%). Mahasiswa non obese yang mengalami hiperurisemia 8 orang (38\%) dan yang tidak mengalami hiperurisemia 13 orang (62\%).

Penelitian ini hanya dilakukan pada jenis kelamin pria karena adanya perbedaan status hormonal yaitu hormon estrogen. Hormon estrogen pada wanita berperan dalam meningkatkan ekskresi asam urat melalui ginjal. Hal ini menjelaskan mengapa peningkatan kadar asam urat pada wanita umumnya terjadi pada usia menopause. $^{14}$

Pada penelitian ini ditemukan 14 orang mahasiswa obes dan 8 orang mahasiswa non obes yang mengalami peningkatan kadar asam urat. Peningkatan kadar asam urat darah pada sampel ini sesuai dengan teori kemungkinan disebabkan oleh karena adanya penurunan ekskresi asam urat pada ginjal akibat resistensi insulin dan hiperinsulinemia yang terjadi pada keadaan berat badan lebih dan obesitas. ${ }^{15}$

Tingginya kadar asam urat pada mahasiswa obes di penelitian ini berhubungan dengan studi yang dilakukan oleh Tsushima tahun 2013 bahwa jaringan lemak dapat memroduksi dan mengekskresi asam urat melalui xanthine axidoreductase
(XOR) sehingga produksi asam urat ini meningkat pada penderita obesitas. ${ }^{16}$

Hiperurisemia pada obesitas terjadi melalui resistensi hormon insulin. Pada tubuh yang akan mengalami obesitas akan terjadi peningkatan pelepasan jumlah asam lemak bebas ke dalam sirkulasi. Masuknya asam lemak bebas yang berlebihan ini ke dalam otot mengakibatkan terjadinya resistensi insulin. Resistensi insulin, hipoksia, dan kematian sel dapat menginduksi perubahan xanthine dengan bantuan air dan oksigen akan berubah menjadi asam urat yang menghasilkan peroksida. Insulin juga berperan dalam meningkatkan reabsorbsi asam urat di tubuli proksimal ginjal. Sehingga pada keadaan hiperinsulinemia pada pra diabetes terjadi peningkatan reabsorbsi yang akan menyebabkan hiperurisemia. ${ }^{8,9}$

Konsumsi makanan sehari-hari dapat mempengaruhi kadar asam urat. Mengonsumsi makanan-makanan seafood dan daging sangat berpengaruh terjadinya gout. ${ }^{17}$ Makanan tinggi purin berkontribusi terhadap peningkatan kadar asam urat darah. Peningkatan kadar asam urat darah pada sampel penelitian ini sesuai dengan teori kemungkinan juga disebabkan oleh adanya penurunan fungsi ginjal. Penurunan fungsi ginjal dapat menyebabkan peningkatan kadar asam urat akibat gangguan dari ekskresi asam urat di dalam ginjal oleh karena penurunan filtrasi glomerulus, penurunan ekskresi tubulus dan meningkatnya reabsorbsi tubulus. ${ }^{18}$

Hasil penelitian yang didapat bukan hanya pada orang obes yang mengalami hiperurisemia, tetapi juga pada non-obes (berat badan normal). Hal ini mungkin disebabkan adanya faktor genetik yang berperan dalam peningkatan kadar asam urat dan berkurangnya aktifitas fisik. Pada penelitian ini didapatkan 7 orang mahasiswa obes dan 13 mahasiswa non 
obes yang memiliki kadar asam urat normal kemungkinan disebabkan oleh fungsi ginjal yang baik, tidak mengkonsumsi alkohol, tidak mengkonsumsi makanan tinggi purin. ${ }^{18}$

Dari hasil penelitian rata-rata kadar asam urat pada mahasiswa obes terlihat ada peningkatan asam urat di setiap pertambahan usia tetapi pada saat usia 21 tahun ada penurunan penelitian ini tidak sesuai dengan studi yang dilakukan oleh Pasifico EL et al. tahun 2009 pada anak dan remaja menemukan bahwa hiperurisemia berhubungan erat dengan obesitas, lebih khusunya penderita sindroma metabolik. Selain itu, hiperurisemia berhubungan erat dengan jenis kelamin laki-laki dan pertambahan usia, ${ }^{19-20}$ tetapi juga penelitian pada mahasiswa non obes terjadi peningkatan di setiap usia meskipun peningkatan itu tidak dikatakan sebagai hiperurisemia.

\section{SIMPULAN}

Pada penelitian ini rerata kadar asam urat pada kelompok obes lebih tinggi secara bermakna daripada kelompok non-obes.

\section{SARAN}

1. Bagi mahasiswa: Memperbanyak aktifitas fisik dan mengatur pola makan, terlebih bagi remaja yang mengalami obes, karena dengan ukuran berat badan yang lebih memiliki kecenderungan timbulnya berbagai macam penyakit.

2. Bagi orang tua: Membantu anak dalam mengatur pola hidup sehat, juga membawa untuk mengontrol kadar asam urat secara berkala untuk menghindari komplikasi yang lebih serius.

3. Sebaiknya dilakukan penelitian lebih lanjut tentang perbandingan kadar asam urat pada obes dan non obes di usia dewasa muda.

\section{DAFTAR PUSTAKA}

1. Lingga L. In: Tinton DP, editor. Bebas penyakit asam urat tanpa obat (Ed I).
Jakarta: Agromedia Pustaka, 2012; p.14.

2. Bergamini C, Cicoira M, Rossi A, Vassanelli C. Oxidative stress and hyperuricemia: Pathophysiology, Clinical relevance, and therapeutic implication in chronic heart failure. European Journal of Heart Failure. 2009;11:444-52.

3. Tehupeiory SE. Artritis pirai (Artritis Gout). In: Sudoyo A, Setiyohadi B, Alwi I, Simadibrata M, Setiati S, editors. Buku Ajar Ilmu Penyakit dalam Jilid II (Ed IV). Jakarta: Pusat Penerbit IPD FKUI, 2007; p.1208-10.

4. Riches PL, Wright AF, Ralston SH. Recent insights into the pathogenesis of hyperuricemia and gout. Human Molecular Genetics. 2009;18:R177-84.

5. Kim SY, Guevara JP, Kim KM, Choi HK, Heitjan DF, Albert DA. Hyperuricemia and risk of stroke: a systematic review and meta-analysis. Arthritis Rheum. 2009;61:885-92.

6. Darmawan J, Rasker JJ, Nuralim H. The effect of control and self - medication of chronic gout in a developing country, 2009. [cited 2014 Oct 6]. Available from: http://www.ncbi.nlm.nih.gov/pubmed /14677190.

7. Rotty L. Gambaran asam urat pada suku Minahasa usia dewasa muda (Tesis). Manado: Bagian Ilmu Penyakit Dalam Fakultas Kedokteran Universitas Sam Ratulangi, 1999.

8. Karimba A, Kaligis S, Purwanto D. Gambaran kadar asam urat pada mahasiswa angkatan 2011 Fakultas Kedokteran Universitas Sam Ratulangi dengan IMT $>23 \mathrm{~kg} / \mathrm{m}^{2}$. Jurnal e-biomedik. 2013;1.

9. Nasrul E, Sofitri. Hiperurisemia pada pra diabetes. Jurnal kesehatan Andalas 2012. [cited 2014 Oct 29]. Available from:

http://www.jurnal.fk.unand.ac.id/artic les/vol_1no_2/86-91.pdf. p.86-91.

10. Guyton AC, Hall JE. Obesitas. In: Rachman LY, Hartanto H, Novrianti A, Wulandari N, editors. Buku ajar Fisiologi Kedokteran (Edisi 11). Jakarta: EGC, 2006; p. 917-24.

11. Departemen Kesehatan Republik Indonesia. Badan Litbang Kesehatan. Riset 
Kesehatan Dasar Nasional. Jakarta: Departemen Kesehatan RI, 2010.

12. Darmawan, John. Komplikasi dan kematian dini akibat asam urat. 2008. [cited 2014 Sept 10]. Available from: www.elithaeri.net/2008/01/04/komplikasi- dankematian-dini-akibat-asam-urat/.

13. Setyoningsih R. Faktor-faktor yang berhubungan dengan kejadian hiperurisemia pada pasien rawat jalan RSUP Dr. Kariadi Semarang. 2009. [cited 2014 Sept 15]. Available from: http://eprints.undip.ac.id/ 25234/.

14. Kumar S, Singh AR, Takhelmayum R, Shrestha P, Sinha JN, et al. Prevalence of hyperuricemia in Chitwan District of Nepal. Journal of college of Medical Sciences-Nepal. 2010;6(2):18-23.

15. Pacifico L, Cantisani V, Anania C, Bonaiuto E, Martino F, Pascone R , et al. Serum uric acid and its association with metabolic syndrome and carotid atherosclerosis in obese children. Eur J Endocrinol. 2009:4552.
16. Donohoue PA. Obesity. In: Kliegman, Stanton, St Geme, Schor, Behrman, editors. Nelson Textbook of Pediatrics (Ed 19). Canada: Elsevier, 2011; p.173-7.

17. Wortmann RL. Gout and Hyperuricemia. In: Firestein GS, Budd RC, Harris Jr ED, McInnes IB, Ruddy S, Sergent JS, editors. Kelley's Textbook of Rheumatology (8th ed.) Philadelphia: Saunders Elsevier, 2009; p.1481-506.

18. Hensen, Putra TR. Hubungan konsumsi purin dengan hiperurisemia pada Suku Bali di daerah pariwisata pedesaan. J Peny Dalam. 2007;8(1).

19. Doshi M, Takiue Y, Saito H, Hasoyamada M. The increase protein level of URATI was observed in obesity/metabolic syndrome model ice. Nucleotides, and Nucleic Acids, 2011;30:1290-4.

20. Kubota M, Nagai A, Tang L, Tokuda $M$. Investigation on hyperuricemia in children with obesity or various pediatric disorders. Nucleotides, and Nucleic Acids. 2011;30(12):1051-9. 